\title{
Repetitio Sententiarum, Repetitio Verborum : Kant, Hamann, and the Implications of Citation
}

\section{Citation}

Hamilton, John T. 2014. "Repetitio Sententiarum, Repetitio Verborum\#: Kant, Hamann, and the Implications of Citation." The German Quarterly 87 (3) (July): 297-312. doi:10.1111/gequ.10211.

\section{Published Version}

10.1111/gequ. 10211

\section{Permanent link}

http://nrs.harvard.edu/urn-3:HUL.InstRepos:23947107

\section{Terms of Use}

This article was downloaded from Harvard University's DASH repository, and is made available under the terms and conditions applicable to Open Access Policy Articles, as set forth at http:// nrs.harvard.edu/urn-3:HUL.InstRepos:dash.current.terms-of-use\#OAP

\section{Share Your Story}

The Harvard community has made this article openly available.

Please share how this access benefits you. Submit a story.

\section{Accessibility}




\section{REPETITIO SENTENTIARUM, REPETITIO VERBORUM KANT, HAMANN, AND THE IMPLICATIONS OF CITATION}

JOHN T. HAMILTON

ABSTRACT: A careful comparison of the citational practices of Immanuel Kant and Johann Georg Hamann aims to divulge salient distinctions that should contribute to and complicate our historical understanding of the Enlightenment project. To this end, the present article begins by investigating Kant's famous gambit in his response to the question "Was ist Aufklärung?" and subsequently traces its links to the philosopher's earlier engagement with his Königsberg neighbor regarding the proposed collaboration to compose a physics textbook for children. What emerges from this investigation is a revealing and at times confounding network of citations, primarily from Horace, which serve to test the limits of critical discourse. At stake is a redefinition of eighteenth-century language theory that takes into consideration crucial positions on the meaning and value of metaphysics, theology, and human nature.

Precisely as a repetition of language, citation entails an act of speaking that is at the same time an act of listening, or an act of writing that also involves an act of reading. ${ }^{1}$ Despite this conjoined effort, citational practice tends to privilege one aspect at the expense of the other, which in turn signals how language itself is believed to operate. The speaker or writer who assumes the role of an assured agent of language generally implements language as an instrument for communicating a thought, while the one who listens to language often regards the words themselves as the generative source of thought and concepts. Insofar as a citation is a repetition, one could specify the former case as a repetitio sententiarum (a repetition of thoughts), which presumes language to be a posteriori, and the latter as a repetitio verborum (a repetition of words), which instead presumes language to be a priori.

\footnotetext{
${ }^{1}$ The present essay was first presented as the Sigmund H. Danziger Lecture in the Department of Classics at The University of Chicago, and subsequently at Princeton University. I would like to acknowledge the extremely helpful questions and suggestions that emerged during the discussion periods, which I have gratefully incorporated into this final version. I would also like to thank the anonymous readers of the manuscript for their insightful and useful input.
} 
This distinction is particularly acute in the alternative approaches that obtain in comparing the citational practices of that oddest couple of the late Eighteenth Century, Immanuel Kant and Johann Georg Hamann. In the starkest terms, whereas Kant reaches for language in order to transmit his thinking, Hamann abides with language as the determinant origin of thought's content. The implications of these opposing presuppositions, however, point well beyond considerations of linguistic functions and instead strike at the very core of what generally counts as the Enlightenment, touching on and complicating fundamental questions of metaphysics, theology, and ultimately human nature.

In addition to providing one of the most important and memorable definitions of the European Enlightenment, the opening paragraph of Kant's response to the question "Was ist Aufklärung?" (1784) already broaches crucial issues regarding the form and function of citations in philosophical discourse.

Aufklärung ist der Ausgang des Menschen aus seiner selbstverschuldeten Unmündigkeit. Unmündigkeit ist das Unvermögen, sich seines Verstandes ohne Leitung eines anderen zu bedienen. Selbstverschuldet ist diese Unmündigkeit, wenn die Ursache derselben nicht am Mangel des Verstandes, sondern der Entschließung und des Muthes liegt, sich seiner ohne Leitung eines anderen zu bedienen. Sapere aude! Habe Muth, dich deines eigenen Verstandes zu bedienen! ist also der Wahlspruch der Aufklärung.

Enlightenment is man's exit from his self-incurred immaturity [Unmündigkeit]. Immaturity is the inability to use one's own understanding without the guidance of another. This immaturity is self-incurred if its cause is not lack of understanding, but lack of resolution and courage to use it without the guidance of another. Sapere aude! Have courage to use your own understanding! is therefore the motto [der Wahlspruch] of the Enlightenment. ${ }^{2}$

Kant's decision to appropriate a tagline from Horace's Epistles is at the very least intriguing. Despite the call to apply one's understanding "without the guidance of another" (ohne Leitung eines anderen)-a qualification that Kant apparently feels compelled to repeat twice verbatim-he allows philosophy to be guided by a

\footnotetext{
2 Immanuel Kant, Beantwortung der Frage: Was ist Aufklärung? in Kant, Gesammelte Schriften (Akademieausgabe), 23 vols. (Berlin: Preussische Akademie der Wissenschaften, 1900ff.), 8: 33-42, here 33 (henceforth cited as AA with volume and page number); "An Answer to the Question: What is Enlightenment?" in Kant, Political Writings, H. Reiss, ed, H.B. Nisbet, trans. (Cambridge: Cambridge University Press, 1991), 54-60, here 54.
} 
classical citation: sapere aude! The resolution to be intellectually self-sufficient, to abandon one's "self-incurred immaturity," is expressed by borrowing a phrase from a poet. The exhortation to think for oneself is prescribed by an external source. The courageous independence of one's intellect is shown to be strikingly dependent. A plea for autonomy-for release from tutelage, for authenticity-curiously relies, still, on prior authority.

Without blinking, Kant emerges from the condition of immaturity or Unmündigkeit, relinquishing the position of an underage child who has no voice or mouth (Mund), by becoming a mouthpiece of poetic tradition or even by allowing tradition to speak for him, here in a text that explicitly challenges authorities and institutions that act as Vormünder, as advocates who dare to speak in the people's stead.

Daß der bei weitem größte Teil der Menschen (darunter das ganze schöne Geschlecht) den Schritt zur Mündigkeit, außer dem daß er beschwerlich ist, auch für sehr gefährlich halte: dafür sorgen schon jene Vormünder, die die Oberaufsicht über sie gütigst auf sich genommen haben. (AA 8: 54)

That by far the greatest part of mankind (including the entire fair sex) should consider the step toward maturity [Mündigkeit] not only as difficult but also as highly dangerous: those guardians [Vormünder] already take care of it, they who have kindly taken upon themselves the task of supervision.

As a legal term, Unmündigkeit denotes the incapacity for self-representation exemplified by the case of children, yet also applicable to the insane, the senile, and - as Kant points out-women. Powerful institutions infantalize the populace by portraying independent thinking as something highly precarious and frightening. They strive to convince society that entrance into self-reliance should be restricted to those accompanied by a legal guardian. In Kant's rating system, too, Enlightenment is decidedly for mature audiences only. However, what distinguishes the philosopher's project is the desire to encourage every citizen to grow up-to examine, judge, and speak for oneself. Thus, Kant rails against the "laziness and cowardice" (Faulheit und Feigheit) that causes the majority to "remain immature" (unmündig bleiben), long after they have naturally come of age. Nonetheless, as already indicated, Kant does not hesitate to import language from other sources. He 
not only cites natural law (naturaliter maiorénnes) but also, more emphatically, a poet. He lets Horace be his spokesman, even if only in passing. With one hand, he decries the "rules and formulas" (Satzungen und Formeln), that mechanically operate as "the foot-cuffs of a perpetual immaturity" (die Fußschellen einer immerwährenden Unmündigkeit), while, with the other hand he cites a poetic formula, implicitly footnoted, making it moreover into the slogan of autonomy, into the very motto (der Wahlspruch) of the Enlightenment, seemingly unaware of any contradiction or irony (AA 8: 33-34).

All the same, it really should come as no surprise that Kant expresses even the notion of intellectual independence by means of a Latin quotation. Since Antiquity, thinkers have been drawn to the pithy utterance, the concise maxim, the well-coined phrase. Modern writers, from the Renaissance of Machiavelli and Montaigne straight through to Kant's Eighteenth Century and beyond, inherited the ancients' inclination to harvest key insights, precepts and viewpoints from the poetic tradition, not out of "laziness" or "cowardice," but rather in order to communicate their own positions with concision and cogency. For Quintilian there is an obvious, authoritative value in the "maxims of poets" (sententiae poetarum):

nam sententiis quidem poetarum non orationes modo sunt refertae sed libri etiam philosophorum, qui quanquam inferiora omnia praeceptis suis ac litteris credunt, repetere tamen auctoritatem a plurimis versibus non fastidierunt. (Inst. orat. 5.11.39)

For not only are speeches full of maxims from the poets, but also the books of philosophers, who, though they believe everything to be inferior to their own precepts and writings, have not disdained to draw on [repetere] the authority from great numbers of verses.

Poetic turns of phrase lend authority to philosophical disquisitions. Even those thinkers most skeptical of public opinion were captivated by the forcefulness of the apothegm, the proverb, and the gnomic utterance, appreciating their potential contribution to thoughtful reflection. In Plato's Protagoras, for instance, Socrates expresses admiration for the Spartans' capacity to philosophize: ${ }^{3}$

\footnotetext{
${ }^{3}$ On the tension between intellectual autonomy and heteronomy in the Protagoras, see Charles L. Griswold, Jr., "Relying on Your Own Voice: An Unsettled Rivalry of Moral Ideas in Plato's Protagoras,"
} 


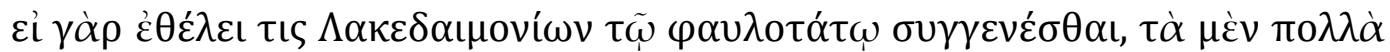

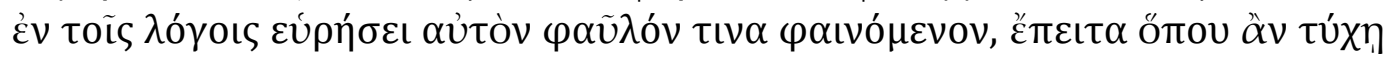

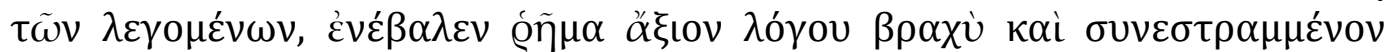

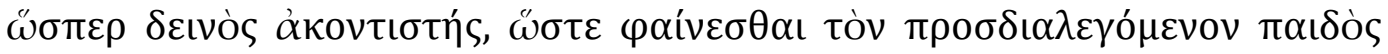
$\mu \eta \delta \dot{\varepsilon} \nu \beta \varepsilon \lambda \tau i ́ \omega($ Prot. 342d-e).

For if anyone is willing to associate with the most ordinary Lacedaemonian, he will find him for the most part to appear ordinary in his speech; but then by chance, at some point in the conversation, all at once, like a skillful lancer, he hurls forth a valuable remark, brief and condensed, so that his interlocutor appears no better than a child.

Socrates goes on to attribute to Spartan ingenuity the seminal maxims of "know thyself" and "nothing in excess," which were inscribed on the Temple to Apollo at Delphi, in order to demonstrate how the first philosophers exhibited this "laconic brevity" ( $\beta \rho \alpha \chi v \lambda$ oүí $\alpha \Lambda \alpha \kappa \omega \nu \iota \kappa \eta ́, 343 b)$. Kant's nomination of sapere aude belongs precisely to this venerable tradition of appropriating the efficacy of a succinct dictum. Indeed, how better to emerge from Unmündigkeit than by reducing one's formidable Vormünder to the level of helpless children!

Of course, Socrates' irony should not be overlooked. Elsewhere, for example in the Gorgias, he rails against the kind of sophistry that cleverly piles on terse poetic citations in the course of a refutation-a practice that he dismisses as a dubious method for discovering the truth. ${ }^{4}$ Nonetheless, as in the Ion, Socrates cannot deny the sheer force of poetic recitation, which derives its magnetic power from the divine Muses. ${ }^{5}$ Moreover, one need only recall the Delphic dictum, "Know thyself" and the central, motivating role it played in Socrates's philosophical mission.

In drawing from the Horatian source, Kant apparently wants to enlist this kind of power. His usage does not necessarily imply dependence as much as it

The Review of Metaphysics 53 (1999), 283-307. For an examination of the Spartans' reputed brevity in speech, see E.D. Francis, "Brachylogia Laconica," BICS 38 (1991-93), 198-212; and E. David, "Sparta's Kosmos of Silence," in Sparta: New Perspectives, S. Hodkinson and A. Powell, eds. (London, 1999), 117-46.

${ }^{4}$ See Plato, Gorgias 471e - 472a.

5 Plato, Ion 536a. 
recalls a notion of authorship that regards the auctor not only as the creator or originator of discourse but also as the one who preserves prior auctoritas, granting it continued existence or even a kind of permanence by vouching for its veracity or present relevance. By evoking the Latin imperative-sapere aude!-Kant can hardly be charged with dogmatism. On the contrary, he strives to reveal a fundamental, universal trait of human, intellectual courage, reminding his readers of what Horace already knew, hoping to reawaken a spirit of independent inquiry that is otherwise silenced by the Church, the State, and other oppressive institutions. Against these intimidating sovereigns, Kant summons Horace to marshal a counter-force, to inspire intellectual self-sufficiency and autonomy. The philosopher, therefore, does not succumb to power as much as he draws it to his side; and this alignment of power entails reciprocal effects: In the course of legitimizing his own discourse by means of citation, Kant also establishes Horace's legitimacy for the Enlightenment. That is, we are dealing with the transference and maintenance of power, one that confirms the authority cited, while empowering the author who cites. ${ }^{6}$

This conjoined power enhances philosophical presentation and has consistently contributed to its clout and validity. As Aristotle notes in his Metaphysics, quotation is one of three viable methods for granting a discourse credibility and currency:

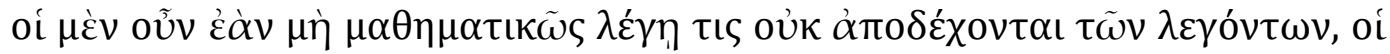

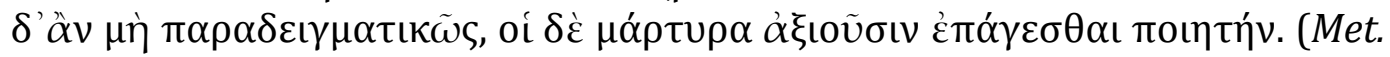
2, 995a7-8)

Some people do not accept statements unless you express them mathematically; others, unless by way of examples; while others deem that one call in a poet as a witness.

Along with mathematical proofs and paradigmatic illustrations, poetic quotations find their place in ancient philosophical discussions precisely as items that

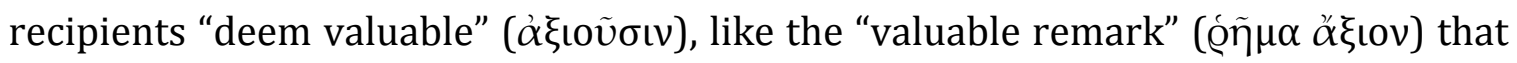

\footnotetext{
${ }^{6}$ Cf. Peter Pütz, "Autorität durch Wiederholung: Von der Herrschaft des Zitats," in Autorität der/in Sprache: Literatur, Neue Medien, J. Fohrmann, ed. (Bielefeld: Aisthesis, 1999): 694-704; here, 695.
} 
Socrates found so impressive among the Spartans. ${ }^{7}$ Should a philosopher strive to ascertain and impart knowledge, he would be expected to deal directly with the anterior body of sophia displayed by the poets. Accordingly, for an audience steeped in poetic culture, it is worthwhile to summon a poet's voice, either for points of verification or contestation.

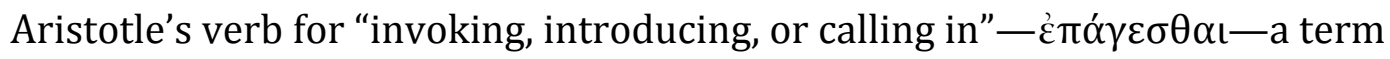
almost perfectly replicated in the modern German anführen, engages the metaphor of calling someone in as a witness before a judging party, of summoning a person in court to provide testimony. The juridical image is further operative in the Latin citare, which is composed from the perfect passive participle of cierre ("to cause to move, stir, drive, or shake") and cognate with the Greek кıvعiv ("to put in motion"). A passage cited is one that has been called to appear, made to move from one context to another, perhaps even shaken loose from its initial setting. Yet, this kinetic energy is not always amenable to control-the citation as attestant or testifier always stands in a position to become a hostile witness. This possibility is grounded in the fact that the testimony adduced by citation can never be entirely absorbed by the new, incorporating text. In addition to the synchronic axis (how the citation relates to the present discourse), there is also the diachronic axis (how the citing text relates back to the cited discourse); and the energy that is ignited by the friction between the synchronic and the diachronic, between repetition and difference, derivation and innovation-also stands to disrupt the adoptive context. ${ }^{8}$

In Kant's essay, the potential disruption is signaled by the verbal intrusion of the citation, which is both lexically and typographically marked. In hitting upon the italicized phrase sapere aude, the person who reads Kant's piece encounters an opening that leads away from the text at hand and toward prior sources. Needless to say, the first step onto this intertextual path would be to consult, with or without Kant's sanction, the second poem from Horace's first book of Epistles. Here, the poet attempts to persuade Lollius Maximus, a young student of rhetoric, to devote

\footnotetext{
${ }^{7}$ On the value and function of poetic quotations in ancient philosophy, see Stephen Halliwell, "The Subjection of Muthos to Logos: Plato's Citation of the Poets," Classical Quarterly 50 (2000): 94-112.

${ }^{8}$ See Stefan Morawski, "The Basic Function of Quotation," in Sign, Language, Culture, C.H. van Schooneveld, ed. (The Hague: Mouton, 1970), 690-705, here 692.
} 
himself to the Homeric poems as a repository of moral philosophical precepts. Rather than waste one's youth on the pursuit of wealth and pleasure, like Penelope's suitors, one should devote serious time to studying the principles of virtue and wisdom by way of exemplary poetry, before it is too late:

dimidium facti qui coepit habet; sapere aude;

incipe! qui recte vivendi prorogat horam, rusticus exspectat dum defluat amnis; at ille labitur et labetur in omne volubilis aevum.

(Horace, Epist. 1.2.40-4)

He who begins has half the deed done: dare to be wise:

begin! He who postpones the hour of living rightly,

is like the farmer who waits for the river to run off; but the river

flows past and will flow, rolling along for all time.

Horace's eminently quotable bid (sapere aude) itself follows on the heels of proverbial wisdom: dimidium facti qui coepit habet, which translates the Greek

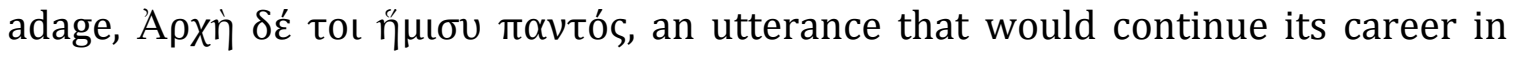
most European languages: for instance, in the French (Il est bien avancé, qui a bien commencé), the German (Frisch gewagt ist halb gewonnen), or the English (Once begun is half done). In Horace's epistle, it is this gnomic keenness that characterizes the poet's advice as especially paternal and direct.

Returning to Kant's usage, what the initial poetic context reveals is that sapere aude should be understood in a moral and not a cognitive sense. In Horace's poem, the command refers to the careful study of epic poetry, and not, as Kant implies, a resolute rejection of dogmatic guidance. Kant's exhortation, calling for the intellectual emancipation from the "guidance of another," contrasts with Horace's initial recommendation, which promotes Homer as a moral advisor of virtue. It is noteworthy that Horace suggests the reading of poetry and not philosophy for moral instruction. Although both Horace and Kant allude to hesitation and childishness, the philosopher's admonition-"dare to know," dare to have the courage to use your own understanding" - is addressed to someone who lacks scientific curiosity, while the poet's encouragement, "dare to study true wisdom," is aimed at the hedonistic 
procrastinator, who, like a foolish rustic, refuses to cross the river until the waters run dry.

In summoning the phrase sapere aude, Kant may have been motivated by Pierre Gassendi, who, a century earlier, had already refitted Horace's admonition to express a modern appeal for free inquiry. Gassendi, who imprinted all his books with the Horatian line, enlisted the phrase to argue explicitly against virtue, which the scientist regarded as conformity to a norm. For Gassendi, himself a precursor of the Enlightenment, sapere aude should inspire the boldness required for the fearless application of critical reason. ${ }^{9}$ The same intention is discernible in an earlier text that Kant published a year before the Aufklärung essay, namely his Prolegomena to any Future Metaphysics, which also includes a reference to Horace's epistle. In the introductory pages, Kant addresses philosophers who have hitherto been reluctant to pose the simple question, "Whether such a thing as metaphysics is at all possible?" (AA 4: 255). According to Kant, the reason why philosophers have hesitated to ask this fundamental question is because, by inquiring into the possibility of a science, one implicitly doubts its actuality. For Kant, this sheepishness is yet another instance of the cowardice that obstructs the establishment and elaboration of sound metaphysics. The "reader who thinks for himself" (der selbstdenkende Leser) must not cower in apprehension, for the demand to form the foundations of any future metaphysics will not disappear merely by neglecting to cross the treacherous waters of doubt. To illustrate, Kant appends a footnote that simply cites the simile from Horace's epistle (rusticus exspectat [AA $4: 257])$.

In essence, Kant uses Horace's words to express his own ideas. He employs Horace's utterance without full regard for the initial act of utterance-the énonciation is subordinated to or dissolves into the énoncé. This verbal appropriation clearly correlates to the free use of reason: the capacity to repurpose or even abuse an inherited quotation corresponds to the rational autonomy that Kant champions throughout his piece. As a consequence, Kant reduces the intrusion

\footnotetext{
${ }^{9}$ For an overview of modern adoptions of the Horatian motto, see Franco Venturi, "Sapere aude!" Revista storica italiana 71 (1959): 119-28.
} 
of the quoted text to a minimum. A reader may or may not stammer at the sudden appearance of a poetic citation in Kant's philosophical exposition; the point is that this reader is expected to move past the interruption without further ado, to continue reading Kant's essay rather than pause and reach for an edition of Horace's Epistles. To be sure, Kant repeats Horace's language, but it is specifically a repetition of an idea, a repetitio sententiae, an idea, moreover, that Kant himself aims to steer with rational, sovereign control. To this end, the signified-that which is presented as ideational content-must take precedence over the initial form that voiced the signifiers; the vox and its words (verba) must yield to the thought expressed in words or the sententia. ${ }^{10}$ Kant is more concerned with communicating a thought than with transmitting the discourse that mediates the thought. Although necessary for transmission, Kant's exposition relies on the principle of the vanishing medium: once the idea is received, the discourse itself is dispensable. A writer who is simply content to repeat words, to insert into his or her text a repetitio verborum, is, at least in Kant's assessment, as foolish as an underage child or a farmer waiting for the river to drain out.

It is precisely this kind of foolishness or childishness that we discover in the work of Kant's fellow neighbor in Königsberg, his rather difficult friend, Johann Georg Hamann. Hamann's writings, which are generally regarded as documents of a counter-Enlightenment, are indeed notoriously obscure, dense and abstruse, at once pious and humorous, ironic and bawdy, perplexingly digressive and saturated with countless allusions and citations from the Bible, Greco-Roman antiquity and European letters. As Goethe famously quipped, when reading Hamann, "one must completely rule out what one normally means by understanding." 11 The difficulty of Hamann's work may be explained by his refusal to follow the principle of the vanishing medium. For him, discourse, which is bound to a unique historical and

\footnotetext{
${ }^{10}$ For further discussion, see Antoine Compagnon, La seconde main, ou le travail de la citation (Paris: Seuils, 1979), 149.

${ }^{11}$ Johann Wolfgang von Goethe, Aus meinem Leben: Dichtung und Wahrheit, in Werke (Hamburger Ausgabe), 14 vols., E. Trunz, ed. (Munich: Deutscher Taschenbuch Verlag, 1981), 9: 515. For an excellent overview of Hamann's early reception, see Johann Georg Hamann: Der hellste Kopf seiner Zeit, 0. Bayer, ed. (Tübingen: Attempo, 1998).
} 
cultural context, is never simply dispensable. The words of the discourse-that is, the concrete verba-possess value in themselves. Hamann's writings are replete with citations because citations are examples of language that are not exhausted in their original enunciation; they persist beyond their initial purpose, having broken free of the primary communication, while still retaining the qualities of their provenance. This liberation from and continuation of the first communicative context is the earmark of poetic discourse, which is thereby distinguished from the ordinary speech that treats language as a perishable commodity. ${ }^{12}$ As we shall see, Hamann's approach reveals a disavowal on Kant's part: Kant cites Horace to lend a certain value to his own discourse, yet he does so by enforcing the dissolution of the poetic medium-a medium that is in fact the very source of the value he wishes to exploit. In striving to make his own, new thought visible, Kant must render the old, initial discursive situation invisible. The fate of Lollius's moral education should have no bearing on Kant's project of enlightenment. In contrast, Hamann insists on savoring the discourse itself, indulging in its depth and opacity. His starting point is the starting point for every devout Christian: In principio erat Verbum. Rather than follow the principle of the vanishing medium, Hamann attends to the principal medium, the human verba, which he takes to be analogous to the redemptive Verbum.

The contrast between Kant's and Hamann's practices of citation is especially vivid in their exchange from 1759, regarding Kant's proposal to collaborate on a physics primer for children-a project that Kant had hoped would lure his friend back to the side of enlightened free thought and thus temper the religious fanaticism that Hamann had been exhibiting since his recent major conversion in London. ${ }^{13}$ At

\footnotetext{
${ }^{12}$ Cf. Gian Biagio Conte, The Rhetoric of Imitation: Genre and Poetic Memory in Vergil and Other Latin Poets, C. Segal, ed. (Ithaca: Cornell University Press, 1986), 41. I borrow the phrase "perishable commodity" from Conte.

${ }^{13}$ On the proposed project to collaborate on the physics book for children, see Reiner Wild, "Natur und Offenbarung: Hamanns und Kants gemeinsamer Plan zu einer Physik für Kinder," in Geist und Zeichen: Festschrift für Arthur Henkel zu seinem sechzigsten Geburtstag, H. Anton, B. Gajek, and P. Pfaff, ed. (Heidelberg: Winter, 1977), 452-68; Hans Graubner, "Physikotheologie und Kinderphysik: Kants und Hamanns Plan zu einer Physik für Kinder in der physikotheologischen Tradition des 18. Jahrhunderts," in Johann Georg Hamann und die Krise der Aufklärung, Acta des fünften internationalen Hamann-Kolloquiums (1988), B. Gajek and A. Meier, ed. (New York: Lang, 1990), 117-45; and John R.
} 
first, Kant plotted with Hamann's employer, Johann Christoph Berens, who was equally troubled by their friend's extreme religiosity, and suggested that Hamann translate portions of Diderot's Encyclopédie-a proposal that Hamann flatly dismissed. Kant subsequently replied with the children's physics project. This time, Hamann's interest was sparked.

In his idiosyncratic fashion, Hamann entertains the plan, while assuming an altogether playful, whimsical tone. In his first letter in response to Kant, before inscribing any greeting, Hamann opens with an epigraph from Horace's Odes 1.27:

- - ah! miser,

Quanta laboras in Charybdi

Digne puer meliore flamma!

- - ah! wretched one, how much you labor in Charybdis a boy worthy of a better flame!

(Horace, Odes 1.27.18-20)

Hamann, too, shakes some lines out of their initial context to speak to new circumstances. Whereas Horace's ode teases a young man wounded by a disastrous love affair, Hamann applies the verses to lament the vain labors of his friend, who, he suggests, is being drawn down into the horrifying whirlpool of philosophical rationalism..$^{14}$ The epigraph implies that Kant is the miser puer, the wretched boy who fancies himself to be mature enough to brave the monstrous maelstrom. Horace interestingly evades mentioning Charybdis's twinned threat, Scylla, and instead speaks of a "better flame." What, then, would represent this improved love affair for Hamann? Moreover, would this erotic investment be without danger or would it be but another monster posing as a blessing? Given Hamann's insistence on Christian conversion, the alternative to the frightening whirlpool of pure reason might well be understood as religious faith, as an open engagement with God, which is not, of course, achieved without sacrifice and therefore risk.

Betz, After Enlightenment: The Post-Secular Vision of J.G. Hamann (Oxford: Wiley-Blackwell, 2009), 84-87.

${ }^{14}$ Cf. Betz, After-Enlightenment, 84-85. 
In addition to staging a structured dilemma, and emphatically unlike Kant's own use of citation, which passes over the initial discursive situation, Hamann allows Horace's erotic setting to impinge upon and color his message. Tellingly, when Hamann publishes his first two replies to Kant, he titles them specifically as "Two Love Letters" (Zugabe zweener Liebesbriefe). ${ }^{15}$ That is to say, in contrast to Kant's citational practice, Hamann invites the reader to consult Horace's erotically driven poem. ${ }^{16} \mathrm{He}$ does not neglect the original énonciation in favor of a more amenable énoncé, but rather allows it to intrude, to cause an interruption, to transform his consideration of a scholarly proposal into a personal love letter. Rather than gloss over the consequences of his citation's provenance, Hamann gives free rein to the ramifications of performing a repetitio verborum. It takes a boy to know one.

In starting the letter proper, Hamann maintains the amorous context while brusquely shifting metaphors, not without sarcasm:

Die Gönner Ihrer Verdienste würden vor Mitleiden die Achseln zucken, wenn sie wüßten, daß Sie mit einer Kinderphysick schwanger giengen (369).

The benefactors of your merits would shrug their shoulders in pity, if they knew that you went about pregnant with a children's physics book.

The guiding image, which relates authorship to childbearing, in addition to transfiguring the addressed philosopher from a miserable adolescent to an expectant mother, also alludes to that key philosophical tradition instigated in Plato's Symposium, where Diotima, in her famous account of Eros, distinguishes the two alternate drives for achieving immortality. In Diotima's view, of course, "all men are pregnant": some seek to reproduce corporeally, while others strive to engender

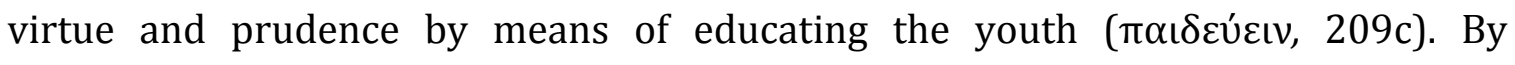
portraying Kant as someone pregnant with an educational treatise, Hamann either

\footnotetext{
15 In Hamann, Fünf Hirtenbriefe ("Five Pastoral Letters" [1763]), Sämtliche Werke, 6 vols., J. Nadler, ed. (Vienna: Herder, 1950), 2: 369-74. My citations are from this edition.

16 On Hamann's engagement with sexuality in relation to his general theories of language and knowledge, see Gwen Griffith-Dickson, "God, I, and Thou: Hamann and the Personalist Tradition," in Hamann and the Tradition, Lisa Marie Anderson, ed. (Evanston: Northwestern University Press, 2012), 55-66.
} 
preserves Diotima's distinction between somatic and soulful reproduction or cleverly allows both interpretations to converge.

The letter eventually reveals Hamann's main point. He points to the difficulty of writing for children, which he claims would require transforming oneself into a child, for only a childish author could communicate in a language understandable by children. Hamann then asks if Kant is truly up to this bold task.

Sich ein Lob aus dem Munde der Kinder und Säuglinge zu bereiten! - an diesem Ehrgeiz und Geschmack Theil zu nehmen, ist kein gemeines Geschäfte, das man nicht mit dem Raube bunter Federn, sondern mit einer freywilligen Entäußerung aller Überlegenheit an Alter und Weisheit, und mit einer Verläugnung aller Eitelkeit darauf anfangen muß. Ein philosophisches Buch für Kinder würde daher so einfältig, thöricht und abgeschmackt aussehen müssen, als ein Göttliches Buch, das für Menschen geschrieben. Nun prüfen Sie sich, ob Sie so viel Herz haben, der Verfasser einer einfältigen, thörichten und abgeschmackten Naturlehre zu seyn? Haben Sie Herz, so sind Sie auch ein Philosoph für Kinder. Vale \& sapere AVDE! (372)

To manage to receive praise from the mouth of children and infants! - To take part in this ambition and taste is no ordinary business, which one must begin not by stealing colored feathers, but rather by voluntarily relinquishing all superiority in age and wisdom and renouncing all vanity. A philosophical book for children, therefore, would necessarily appear as simplistic, foolish, and tasteless as a divine book written for human beings. Now test yourself: Do you have enough heart to be the author of a simplistic, foolish, and tasteless theory of nature? Take heart, for then you are also a philosopher for children. Vale et sapere AUDE! (85)

Unlike Kant's underage (unmündige) cowards, Hamann's children and infants explicitly have a "mouth." Is Kant capable of receiving praise "aus dem Munde der Kinder," "from the mouth of children"? Hamann compares the proposed physics book for children to the Christian gospel, that "divine book written for human beings." Thus, in considering Kant's proposal, which the philosopher had hoped would rekindle his friend's allegiance to the Enlightenment, Hamann stays true to his religious convictions, resorting to a reflection on the Christian mystery of divine kenosis and incarnation, of God's self-humiliation, his loving condescension to mankind. For Hamann, the philosopher who is willing to accommodate his scientific approach to the level of children is analogous to the God who voluntarily descended to a less dignified state, to the God who "relinquished his superiority." The proposed project-a children's book of physics-would hardly be a testament to the accomplishments of rational investigation, but rather would rather appear as 
"simple, foolish, and tasteless" (einfältig, thöricht und abgeschmackt) as the Christian gospel was initially received: To cite the words from Paul's First Epistle to the

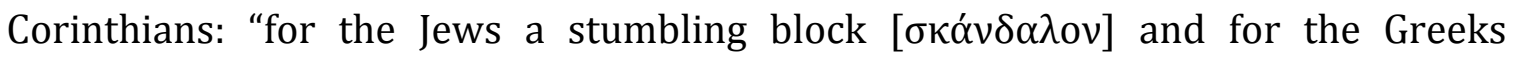
foolishness [ $\mu \omega$ pí $\alpha v]$ " ( 1 Cor. 23). Does Kant have the "taste" to be so "tasteless," the Geschmack to be so abgeschmackt? Certainly, this would be no "ordinary or common or mean business" (kein gemeines Geschäfte). Indeed, would Kant dare to savor what common sense finds insipid?

Throughout his writings, Hamann repeatedly had recourse to Paul's verse from First Corinthians. In fact, they are inscribed on his tombstone in Münster, in the Latin Vulgate translation:

nos autem praedicamus Christum crucifixum Iudaeis quidem scandalum gentibus autem stultitiam, ipsis autem vocatis Iudaeis atque Graecis Christum Dei virtutem et Dei sapientiam, quia quod stultum est Dei sapientius est hominibus et quod infirmum est Dei fortius est hominibus (1 Cor. 23-25)

But we preach Christ crucified, for the Jews a stumbling block and for the Greeks foolishness, but for those who have been called, both Jews and Greeks, Christ is the strength of God and the wisdom of God, because the foolishness of God is wiser than men and the weakness of God is stronger than men.

Hamann's closing imperative, lifted from Horace-sapere aude-thus provokes Kant to dare to taste and thereby acknowledge a foolishness that is wiser (sapientius), to dare to convert his mouth to a child's mouth, in brief, to sense in his own mouth a Eucharistic economy of salvation that reason may judge to be immature, while in fact it exhibits an even higher maturity.

Hamann therefore responds to Kant's proposal with another proposal: Is the philosopher willing to humble himself in this manner or does he merely want "to adorn himself with borrowed plumes"—“sich mit fremden Federn schmücken"— like the jackdaw of the Aesopian fable who proudly flaunts himself, dressed with the plumage of other birds? Can rationalism ever be anything other than a vain philosophical practice that tries to pass off poetic quotations as one's own material? Hamann, too, borrows plumes from other songbirds, but he does so in a decidedly different way, not as someone who proudly speaks as an assured agent of language, but rather as someone who speaks by listening to language. 
Hamann frames his letter to Kant with two citations from Horace, who is thus brought in to bear witness to some truth. He begins with an epigraph from Horace's Odes and concludes with a line lifted from Horace's Epistles. Hardly a rustic sap "who waits for the river to run off," Kant is obliquely depicted as a lovesick boy who bravely plunges into the whirlpool of rational inquiry. Yet, Hamann seems to suggest that, although the philosopher struggles with one monster, he neglects to deal with another, perhaps more worthy opponent. Falling between Scylla and Charybdis, Kant is "miserable," avoiding one danger, while exposing himself to a greater call. In this love letter, Hamann implies that Kant is "worthy of a better flame," a love that would shipwreck his reasoned course. Yet, is the philosopher ready to swallow this difficult truth? For Hamann, the fact that Kant would propose to write a children's book is encouraging; it inspires his love. For, "he who begins has half the deed done."

From this early exchange with Kant straight through to his Metacritique of the Purism of Reason (1784), Hamann insisted on the messy materiality of language, fully recognizing that every repetitio sententiarum is necessarily a repetitio verborum. This insistence is verified by Hegel's assessment: “Hamann's writings do not have a characteristic style so much as they are style through and through."17 Hegel points here to the inseparability of form and content, word and idea, which not only motivates Hamann's use of citation beyond purposes of legitimization or ornamentation, but also corresponds to Hamann's primary article of faith. For Hamann, it is vitally important to regard the incarnation of the Logos, as understood in Christian doctrine, not as mere embodiment or possession but rather as a perfect coincidence of the divine and the human. Consistently throughout his writings, Hamann warns against any slippage into Nestorianism, which sharply distinguishes between the god and the man. He also militates against Docetism, which fails to grasp the human depth of the incarnation and therefore the complete embodiment

\footnotetext{
17 Hegel's review of Hamann first appeared in the Jahrbücher für wissenschaftliche Kritik, October and December 1828. G.W.F. Hegel, "Hamanns Schriften," in Werke, 20 vols., E. Moldenhauer and K.M. Michel, ed. (Frankfurt a.M.: Suhrkamp, 1969 - 71), 11: 275-352, here 281.
} 
of God. As Chalcedonian orthodoxy would establish, Christ did not merely have a human body, he was a human body, just like ideas do not simply have words to express them, but rather are words, firmly grounded in historical and cultural situations. ${ }^{18}$

In Hamann's hands, citation both rests on Trinitarian doctrine and serves as a weapon against what he perceives as the anti-historical position of the Enlighteners. ${ }^{19}$ In his Socratic Memorabilia, addressed to Kant and Berens and published in 1759, Hamann confesses his faith in the final paragraph:

Ist es wahr, daß GOtt Selbst, wie es in dem guten Bekenntnisse lautet, das er vor Pilatus ablegte; ist es wahr, sage ich, daß GOtt Selbst, dazu ein Mensch wurde und dazu in die Welt kam, daß er die Wahrheit zeugen möchte: so brauchte es keine Allwissenheit vorher zu sehen, daß er nicht so gut wie ein Sokrates von der Welt kommen, sondern eines schmählichern und grausameren Todes sterben würde, als der Vatermörder des allerchristlichen Königes, Ludwich des Vielgeliebten, der ein Urenkel Ludwich des Grossen ist. (2: 82)

If it is true that God Himself, as it reads in the good confession which he made before Pilate; if it is true, I say, that God Himself became man and came into the world, that he might bear witness to the truth: if so, then it would require no omniscience to foresee that he would not escape from the world as well as Socrates, but rather would die a more humiliating and more cruel death than the parricide of that most Christian king, Louis the Beloved, who is a great-grandchild of Louis the Great.

There is much that is notable about these concluding lines of Hamann's peroration, which rashly moves from Christ's interview with Pilate and the pronouncement of divine condescension to a pair of comparisons that shifts from the expected to the startling. Although it was not uncommon to correlate Socrates' martyrdom with Christ's passion, the subsequent connection to the torture and cruel execution of the would-be assassin, Robert François Damiens, amounts to an associative tailspin. It is this manner of thinking that Kant would find particularly troubling, an adventurousness that borders on recklessness. Yet, for Hamann, linking the Crucifixion to a regicide's excruciating persecution forms exactly the kind of coincidence of opposites that Hamann found especially appealing, for it forcefully expresses the conjunction of an antithetical pair that confounds any "reasonable"

\footnotetext{
${ }^{18}$ On the importance of Trinitarian doctrine for Hamann's theory of language, see Josef Nadler, Johann Georg Hamann: Der Zeuge des Corpus Mysticum (Salzburg: Müller, 1949): 252 - 53.

${ }^{19}$ Hamann is quite explicit on this point in his Hierophantische Briefe (1774).
} 
abstraction. The same effect obtains here, in the stylistic breach that occurs when sublime theological references yield to an appended and rather mundane account of the lineage of Louis XV. ${ }^{20}$ The audacious foolishness of Hamann's verbal assemblages testifies to the truth of divine condescension. Indeed, understood specifically as a man "who came into the world that he might bear witness to the truth," Christ—as the Word Incarnate, as the amalgam of the highest and the basest, the divine and the mortal, the synchronic and the diachronic - is at least for Hamann the greatest, most powerful citation of all.

Strikingly, Hamann concludes this critique of Enlightenment, dedicated to Kant and Berens-the two men who actively attempted to win him back to the side of Reason-with a rapid listing of three death sentences: the executions of Socrates, Christ, and Damiens. By summoning these figures on history's death row, Hamann would seem to call attention to the lethal power of authorities. This gesture surprisingly anticipates the implicit problem discernible in Kant's later Aufklärung essay, where the philosopher denounces the need for a Vormund only to install himself as a spokesman for the masses. In presuming guardianship for the masses, Kant unavoidably poses as the sovereign judge, who decides on what does and does not count as Enlightenment. What, then, to refer to the preface of Kant's first Critique, would differentiate the philosopher from the "despotic authority," to whom "all must submit"?21 Hamann already appears to warn against the consequences, should the masses refuse to assent to this reeducation program. Fairly or unfairly, in a highly suggestive fashion, Hamann modulates his interrogation of core Enlightenment beliefs into a blatant assignation of guilt.

Culpability will continue to color Hamann's engagement with his century's strongest intellectual beliefs. Twenty-five years later, in 1784, upon reading Kant's response to the question "Was ist Aufklärung?", Hamann composes a long letter to his close friend Christian Jacob Kraus, a professor of practical philosophy and a colleague of

\footnotetext{
20 Cf. James C. O'Flaherty, Hamann's Socratic Memorabilia: A Translation and Commentary (Baltimore: Johns Hopkins University Press, 1967): 79.

${ }^{21}$ Cf. Kant's "Preface" to the first edition of Kritik der reinen Vernunft (1781), in Gesammelte Schriften, 3: viii-xiv.
} 
Kant's at Königsberg. The letter presses the terms of Kant's main argument, in particular the question of "selbstverschuldete Unmündigkeit" ("self-incurred immaturity"). To begin, he points out that an "inability", like the inability to speak for oneself, is hardly a "fault" (Schuld), and then considers where this Schuld-this "guilt, debt, or fault"-in fact lies. His investigative eye falls on the anonymous "other" in Kant's repeated phrase: "without guidance of another."

Wer ist aber der unbestimmte andere, der zweymal anonymisch vorkommt? [...] Antwort: der leidige Vormund, der als das correlatum der Unmündigen implicite verstanden werden muß. Dies ist der Mann des Todes. Die selbstverschuldete Vormundschaft und nicht Unmündigkeit. ${ }^{22}$

Who, however, is the indeterminate other, who twice appears anonymously? [...] Answer: the wretched guardian, who must be implicitly understood as the correlate of those who are immature. This is the man of death. The self-incurred guardianship and not immaturity.

A century and a half before Adorno and Horkheimer, Hamann provides his own dialectic of Enlightenment by identifying the man of reason as the man of death. The one who preaches the universal light of reason is in fact the guilty party. In Hamann's view, he is the one who is lazy and cowardly, someone who dubiously hides behind anonymity. As Hamann goes on to suggest, the guilt-laden Vormund is complicit with political authorities, like the authority of the enlightened despot Frederick the Great, who claims to emancipate his people but only through thorough oppression, implementing the voice of Reason by silencing voices that are deemed to be undignified, like the "entire fair sex." As usual, Hamann has recourse to comic foolishness:

So muß ich schon zu einem maccaronischen Gänsekiel meine Zuflucht nehmen, Ihnen meinen Dank für den beykommenden Berlinschen Christmonath im cantstyle, den der komische Geschichtsschrieber der komischen Litteratur per e wie ein Asmus cum puncto durch Kantschen Styl gegeben, zu übermachen. Zum Sapere aude! gehört auch aus eben derselben Qvelle das Noli admirari!

\footnotetext{
${ }^{22}$ Hamann to Christian Jacob Kraus, Dec. 18, 1784, in Johann Georg Hamann, Briefe, W. Ziesemer and A. Henkel, ed. (Frankfurt a. M.: Insel, 1988), 145 - 48; here, 146. An English translation is found in Garret Green, Theology, Hermeneutics, and Imagination: The Crisis of Interpretation at the End of Modernity (Cambridge: Cambridge University Press, 2000), 207-15. I have used Green's translation, slightly modified, and refer to is excellent explanatory notes.
} 
Thus I must now take refuge in a macaronic quill, in order to bequeath to you my thanks for the enclosed Berlinsche Christmonath in the cant-style, which the comic historian of comic literature has rendered as Kantian style per e, like an asmus cum puncto. To the sapere aude! there belongs also from the very same source the Noli admirari!

Rather than assume the authoritative tone of a Kant, Hamann adopts the "cant" popularized by the Scottish clergyman, Andreas Cant, who preached to his uneducated congregation in low dialect. He thus makes his point by putting a dot on the first vertical stroke of the letter $m$ to expose the asinus or "ass" in the discourse, reminiscent of the way a Hebrew scribe adds vowel points. The ass would appear to be Kant himself, who, in the same issue of the Berlinische Monatschrift in which his Enlightenment essay appears (November 1784), also published his essay, Idea for a Universal History from a Cosmopolitan Point of View ("Idee zu einer allgemeinen Geschichte in weltbürgerlicher Absicht"), in which the philosopher accommodates his style to the cant of the Weltbürger. ${ }^{23}$

That said, also somewhat like an ass, Hamann cheekily botches the final Latin citation: the famous opening of Horace's Epistles 1.6 does not read Noli admirari but rather Nil admirari.

Nil admirari prope res est una, Numici, solaque quae possit facere et seruare beatum.

(Epistle 1.6.1-2)

To marvel at nothing is almost the one thing, Numicius, And the only thing that can make and keep someone blessed.

Is Hamann simply confused? Or is he not, rather, eager to have his addressee hear Horace's advice as itself a quotation from Catullus, and thus as an asinine dig at Kant's notorious bachelorhood?

Noli admirari quare tibi femina nulla, Rufe, velit tenerum supposuisse femur, non si illam rarae labefactes munere vestis aut perluciduli deliciis lapidis. laedit te quaedam mala fabula, qua tibi fertur valle sub alarum trux habitare caper.

\footnotetext{
${ }^{23}$ I am grateful to the anonymous reader of my manuscript, who suggested this line of thinking.
} 
hunc metuunt omnes; neque mirum: nam mala valde est

bestia, nec quicum bella puella cubet.

quare aut crudelem nasorum interfice pestem,

aut admirari desine cur fugiant.

(Catullus 69)

Do not wonder why no woman,

Rufus, wishes to place her soft thigh beneath you,

not even if you should weaken her with a gift of rare clothes

or with the delights of a pellucid gemstone.

What hurts you is a certain bad story, which claims

that under the valley of your armpits a wild billy-goat lives.

This is what everyone fears; and no wonder: for it's really an evil

beast, and no pretty girl wants to sleep with it.

Therefore either kill this cruel plague of noses,

or cease to wonder why they flee.

Hamann, who explicitly states in his letter to Kraus that his three daughters would not react kindly to Kant's dismissal of the "entire fair sex," may be citing Horace incorrectly in order to adduce Catullus's harsh imperative, which could subsequently remind Königsberg's most famous bachelor that he has a body-a body that announces its presence to everyone with a nose. This recollection thus serves as an oblique cue to Jacob Christian Kraus, that he should "not marvel" at his colleague Kant (noli admirari), because his philosophy, in the final assessment, offers nothing worthy of admiration (nil admirari). As Hamann expresses it in another letter from 1784:

Doch die Pudenda unserer Natur hängen mit den Cammern des Herzens und des Gehirns so genau zusammen, daß eine zu strenge Abstraction eines so natürlichen Bandes unmöglich ist. ${ }^{24}$

The pudenda of our nature are so closely connected with the chambers of the heart and the brain that too strict an abstraction of such a natural bond is impossible.

Rather than traffic in ideas stripped of a body, Hamann allows the flesh to come out of cowardly hiding, so as to reveal that a repetitio sententiae is necessarily a repetitio verborum, that the free use of our reason, which demands the subordination of language to thought, invariably entails a lethal abstraction, one that is at fault,

\footnotetext{
${ }^{24}$ Hamann to Johann Friedrich Hartknoch, July 24, 1784, in Briefe, 113.
} 
insofar as it divorces the mind from the body. For Hamann, daring to know would indeed be fatal, should it fail in daring to savor the incarnate truth. 